\title{
Ectoedemia rosae, a new species with disjunct distribution in the French Alps and Norway (Lepidoptera: Nepticulidae)
}

\author{
Erik J. van Nieukerken \& Kai Berggren
}

The new species Ectoedemia rosae is described from France (Hautes Alpes)
near Briançon, where adults were reared from leafmines on Rosa tomentosa
and from adults collected in Norway, Vang, by sweeping bushes of Rosa majalis.
The species belongs to the Ectoedemia angulifasciella group, and is closely related
to E. hexapetalae (Szőcs, 1957) and the montane Rosa feeders E. rosiphila Puplesis,
1992 from Kazakhstan and E. marmaropa (Braun, 1925) from the USA (Utah).
The latter is recorded new for California and Canada: Alberta and British Columbia.
The large distances between the two localities of E. rosae are likely to represent a
disjunct distribution rather than sampling errors and are discussed with respect to
the resemblance in habitat type.
E.J. van Nieukerken*, Netherlands Centre for Biodiversity Naturalis, PO Box 9517,
2300 RA Leiden, The Netherlands. nieukerken@naturalis.nl
K. Berggren, Bråvann terrasse 21, N-4624 Kristiansand, Norway. kberggr@online.no

\section{Introduction}

The genus Ectoedemia Busck, 1907 and particularly the typical subgenus is the best known generic taxon of Nepticulidae in the western Palearctic, with a full revision and recent update (van Nieukerken 1985, van Nieukerken et al. 2010) and with DNA barcodes known for almost all species (van Nieukerken et al. 2012). Of the 48 species in the western Palearctic only seven were described as new in the last 20 years, most originating from the Mediterranean region and western Asia, with the interesting exception of the British E. heckfordi Van Nieukerken et al. 2010. It thus came as a surprise that some adult specimens collected by the junior author in 2005 in the mountains of Norway, just south of Jotunheimen, could not be identified to any known species. This species was briefly treated and illustrated as unnamed species in the Swedish Nationalnyckeln (Bengtsson et al. 2008, van Nieukerken et al. 2010), but incorrectly recorded from Kristiansand. A description as new species was postponed awaiting further material.

As often in such cases it was serendipity that solved the riddle of this species and let the senior author discover it unexpectedly two years later at a locality 1800 kilometres to the south. During his holidays in 2007 he visited the area near Briançon in the French Alps, having in mind that he might be able to find the hostplant and larvae for E. hexapetalae (Szőcs, 1957), found there earlier by Bengt Bengtsson (van Nieukerken et al. 2006, van Nieukerken et al. 2010). While pitching up the tent on exact the campsite that Bengtsson had suggested, he noticed unknown leafmines on a rose bush just one meter away from 


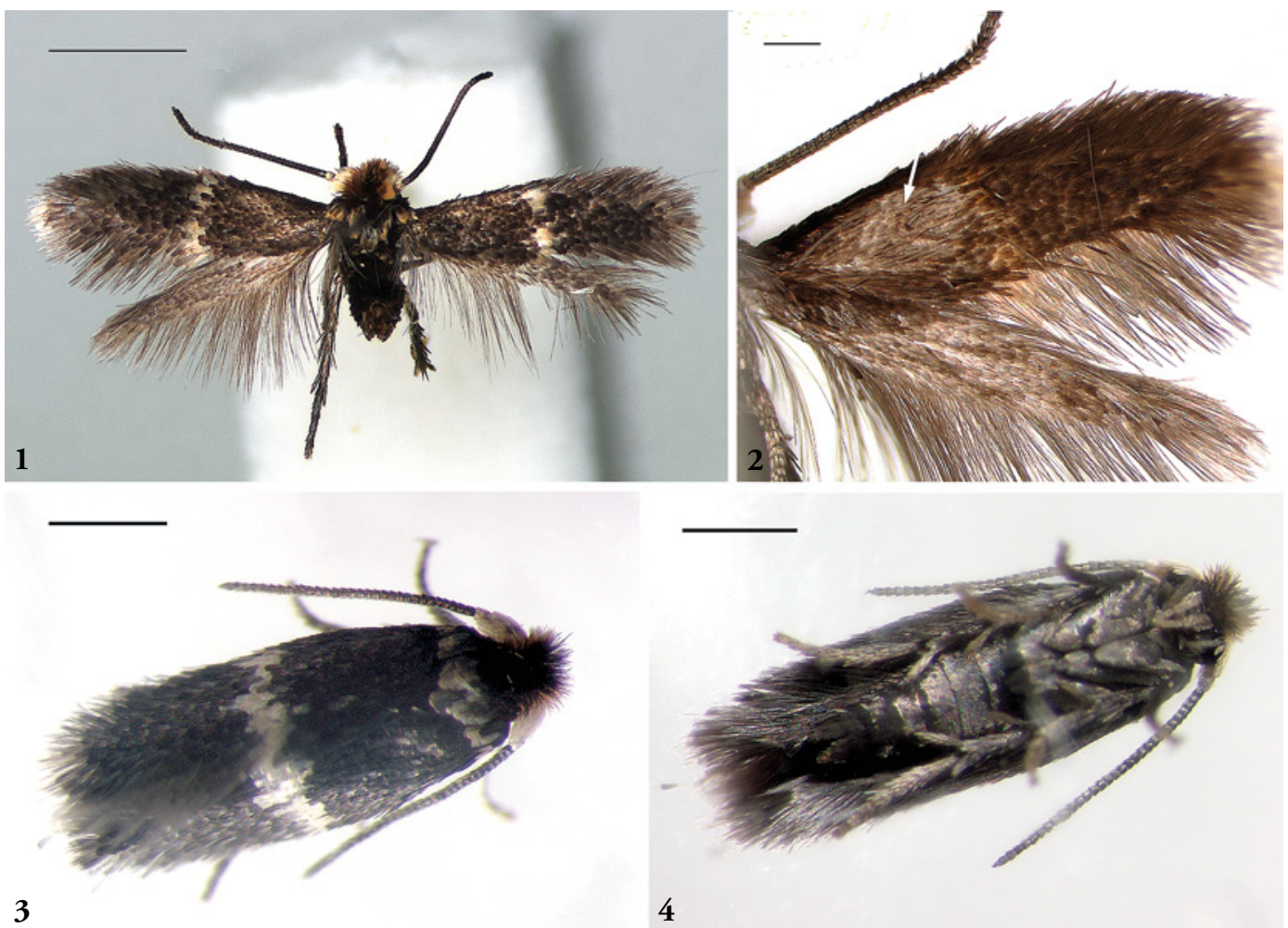

Figs 1-4. Ectoedemia rosae, male holotype habitus. - 1, Dorsal aspect; 2, Ventral aspect of wings, showing patch of white hairscales (arrow) on forewing base; 3-4, Live specimen (paratype) just after emergence. Scales resp. $1 \mathrm{~mm}$, $0.2 \mathrm{~mm}, 0.5 \mathrm{~mm}(3 \& 4)$.

the tent. In the next days he was able to collect about 75 larvae on just three bushes of Rosa tomentosa, all on or near the camping, whereas it could not be found on any other bush of this or other Rosa species in the surroundings. After collecting he considered it possible that these mines belonged to E. hexapetalae, although they were somewhat different from those on its usual host Filipendula vulgaris, but this could possibly be explained by the different leaflet sizes. However, the morphology and DNA barcode of reared specimens the following year showed it to be identical to the Norwegian species. Here we describe it as new and compare it with related species.

\section{Methods}

The description is an addition to the previous revisions (van Nieukerken 1985, van Nieukerken et al. 2010), terminology and methods for preparation, illustrations and measurements follow the last paper. Abbreviations for collections follow Evenhuis (2007).

\section{Ectoedemia (Ectoedemia) rosae sp. n.}

Figs 1-12, 18-21, 24-26

Ectoedemia n. sp.?: Bengtsson et al. 2008: 273.

Ectoedemia (Ectoedemia) sp. n.: van Nieukerken et al. 2010: 68 .

Type material. Holotype $\widehat{\delta}$ : France (Hautes Alpes), Vallée de la Clarée, Les Alberts, Le Bois de Boulogne, UTM: 32T LQ171781, 1375 m, 16-19.viii.2007, leafmines on Rosa tomentosa, Pinus sylv. and riverine forest on limestone, emerged 8-27.iv.2008, E.J. van Nieukerken, RMNH/EvN no 2007092, Genitalia slide EvN 4203, RMNH.INS.24203, DNA extracted (RMNH).

Paratypes: $10 \widehat{0}, 5 q$. France: $7 \widehat{\delta}, 2 q$, same data as Holotype, genitalia slides EvN 3911 $0,4201 \hat{\delta}$, 4202 ㅇ (RMNH). Norway (Oppland): 10 , Vang, Døtten, [UTM: 32V] MN727816, 5.vi.2005, K. Berggren; $2 \hat{0}, 1$, same data, 9.vi.2005, genitalia slides EvN37410, KBE57040, KBE5707우 (RMNH, coll. Berggren); 2 , same data, 16.vi.2008 (coll. Berggren). 


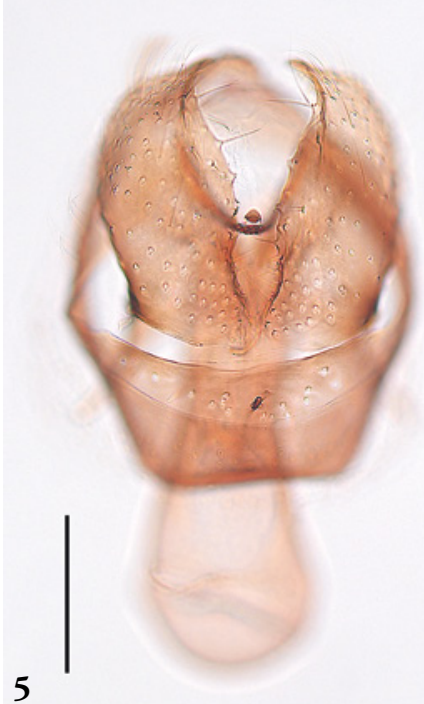

5

6

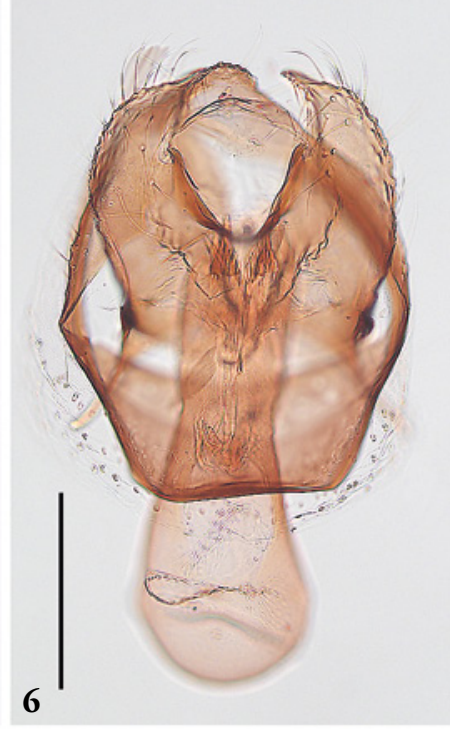

7.
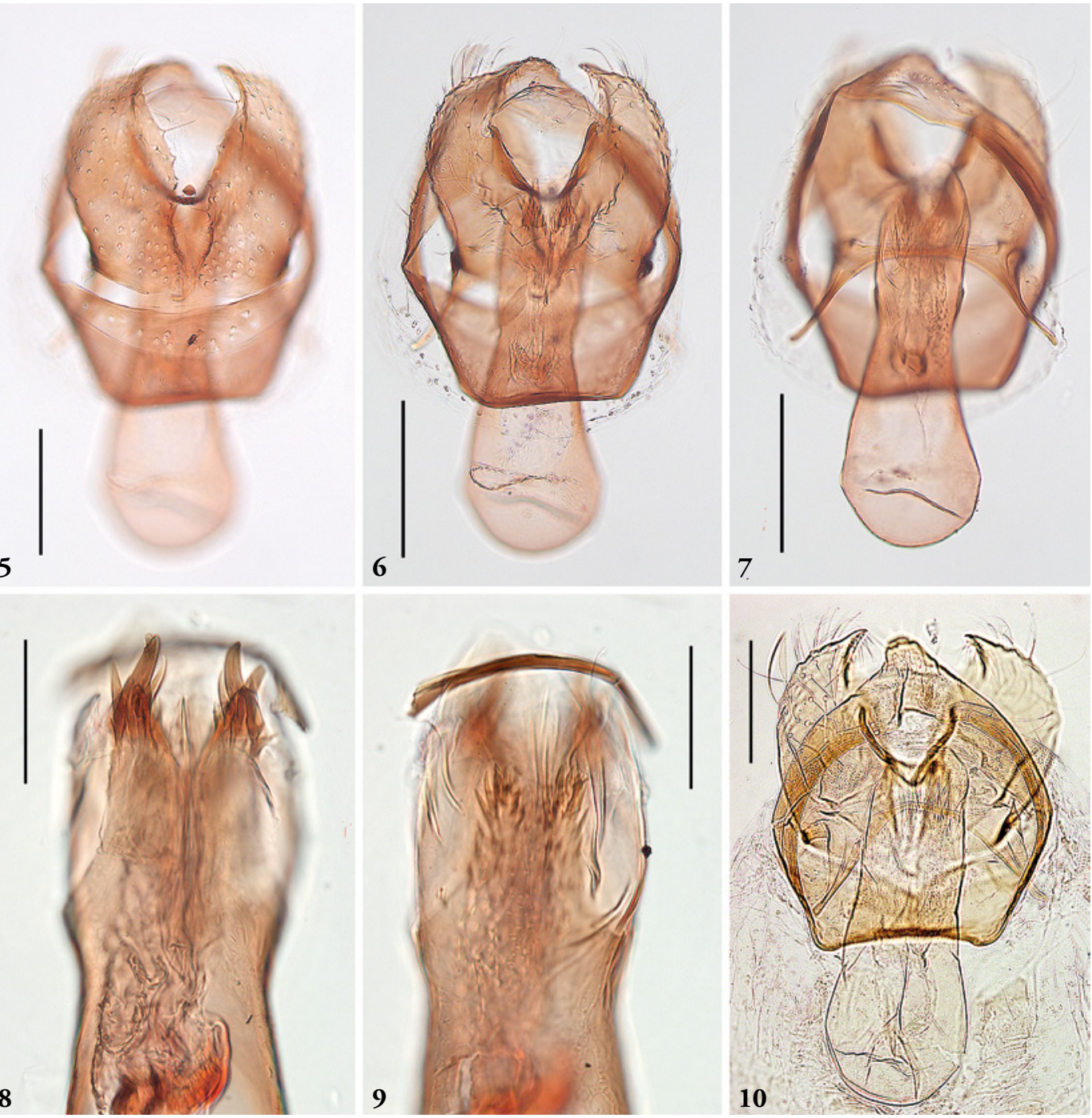

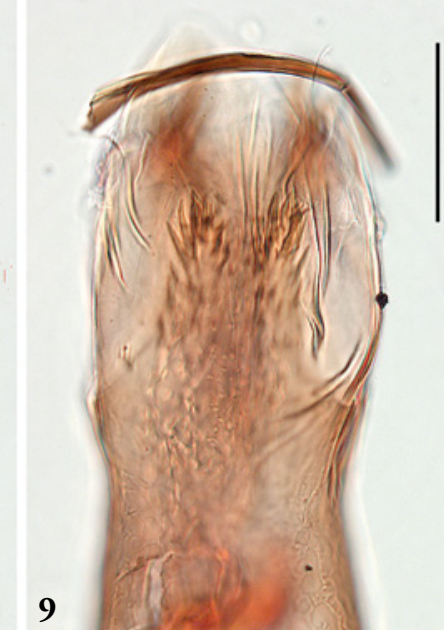

Figs 5-10. Ectoedemia rosae, male genitalia, holotype, slide EvN4203 (5-7); paratype France slide EvN3911 (8, 9), paratype Norway slide KBE5740 (10). -4-6, Genitalia complete, various focus levels; 8, 9, details of aedeagus, respectively from ventral and dorsal, 10, genitalia complete. Scales $100 \mu \mathrm{m}$, for Figs 8-9: 50 $\mu \mathrm{m}$.

\section{Diagnosis}

Ectoedemia rosae can be recognised by the combination of a partly black head and a non metallic white fascia. Most similar E. spiraeae and E. hexapetalae usually have a paler head, occasionally brown in the latter, and the males lack the hairpencil and androconial scales on forewing underside. E. rubivora has also a dark head, usually completely black, and white hairpencil, but the vestiture is darker and the fascia clearly metallic silver. Male genitalia of E. rosae are characterised by the dorsal spinose process, also present in E. hexapetalae, but compared to that species,
E. rosae has many more spines around the ventral carinae, and $E$. hexapetalae has an undivided gnathos. Female genitalia differ from $E$. hexapetalae and all species in the angulifasciella group by the absence of pectinations on the bursa wall.

\section{Description}

Male (Figs 1-4). Forewing length 2.0-2.2 mm (2.1 \pm 0.1 , 9) (holotype 2.24), wingspan $4.5-4.7 \mathrm{~mm}$. Head: frontal tuft dark fuscous to almost black in middle, lateral tufts on vertex paler, ferruginous; collar fuscous to black; antenna with 33-37 segments 

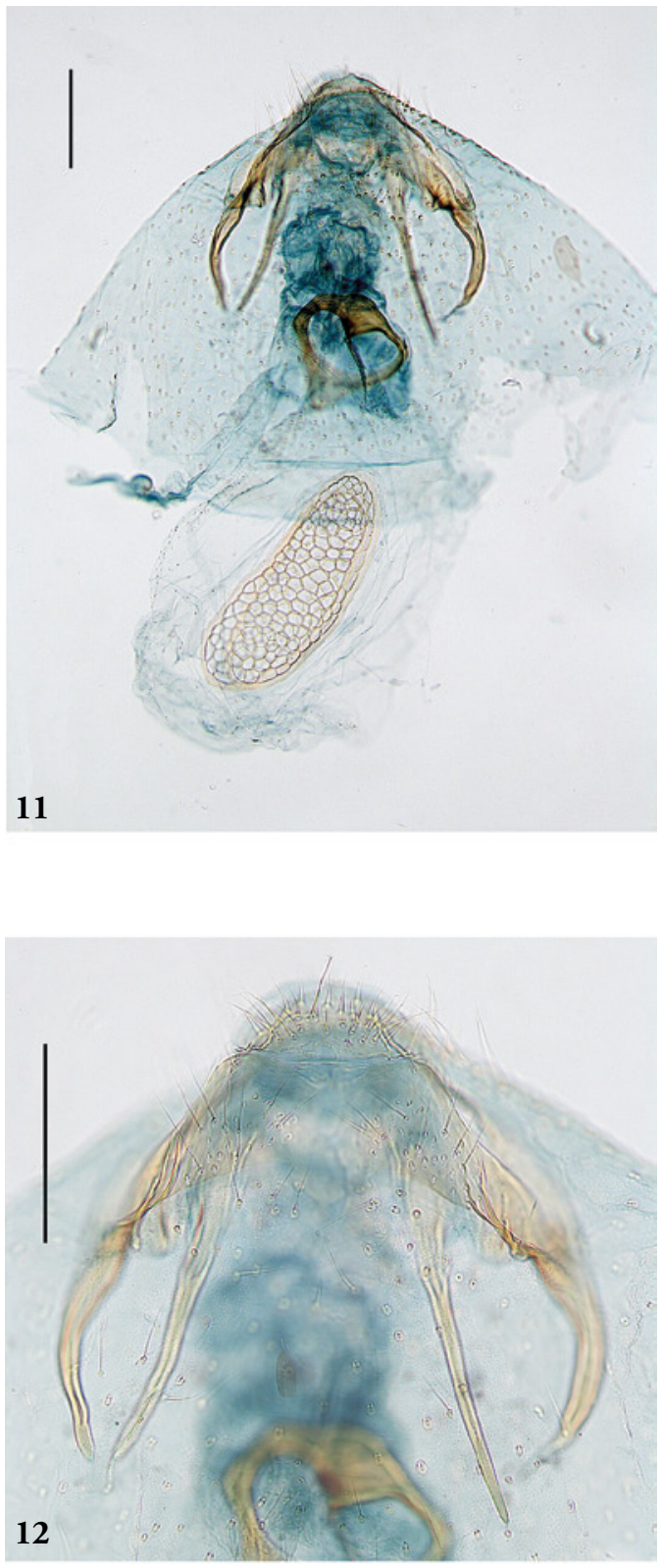

Figs 11-12. Ectoedemia rosae, female genitalia, paratype France, slide EvN4202. Scales $100 \mu \mathrm{m}$.
$(33.9 \pm 1.6,8)$ (holotype 36$)$, scape cream white; flagellum fuscous. Thorax grey fuscous, posterior part often creamy white; forewing dark fuscous, coarsely scaled; a narrow medial white fascia, not or hardly metallic, sometimes broken into two spots; cilia line present. Hindwing and cilia grey brown, hindwing at base with white hairpencil of about $1 / 3$ hindwing length; forewing underside dark fuscous with narrow, white androconial scales in basal half (Fig. 2), hindwing underside dark fuscous. Abdomen upperside fuscous, almost black, with pair of fuscous anal tufts, underside paler, grey.

Female. Forewing length $2.2-2.3 \mathrm{~mm}(\mathrm{n}=2)$, wingspan 5.0-5.2 mm, antennae with 26-27 segments. As male, but hairpencil and androconial scales on forewing underside absent, abdomen without tufts, tapering towards rather pointed abdominal tip.

Male genitalia (Figs 5-10). Capsule 245-270 $\mu \mathrm{m}$ long. Tegumen distinctly produced into rather blunt pseuduncus. Gnathos divided into short distal element, and basal part with serrate margin. Valva 185$195 \mu \mathrm{m}$ long, relatively broad, inner margin slightly serrate from protruding hair-sockets, tip pointed. Aedeagus 295-310 $\mu \mathrm{m}$ long, distinctly longer than capsule, relatively broad; with pair of ventral carinae, each consisting of several spines, and a single dorsal projection with many spines; vesica with small inconspicuous cornuti.

Female genitalia (Figs 11-12). T8 with two lateral patches of scales and ca. 16 setae in total. Anal papillae with ca 13 setae each. Vestibulum with vaginal sclerite, ventral projection thin or indistinct, without spiculate pouch. Corpus bursae ca $590 \mu \mathrm{m}$ long, devoid of pectinations; signa almost similar, 225$250 \mu \mathrm{m}$ long, 2.4-2.9 times as long as wide. Ductus spermathecae with ca. $2 \frac{1}{2}$ convolutions.

Larva (Fig. 18). Very pale greenish white in the mine, with pale brown headcapsule, ventral plates in earlier instars completely absent, ganglia not easily visible. In mine with ventral side upwards.

\section{Biology}

Host plant. Rosa tomentosa Sm. (Rosaceae) in France, in Norway most likely $R$. majalis J. Hermann. The moths in the Norwegian locality were swept near and on the rose bushes.

Egg. Invariably on leaf underside (about 20 checked). Mine (Figs 18-20). Starts as a much contorted narrow gallery in underside parenchyma, often hard to see from upperside, with a thick line of broken brown to black frass (appearing green from upperside); later frass more dispersed and black; in last instar mine suddenly enlarged in roundish or elongate blotch and becoming full depth mine; often several mines on one leaflet, sometimes converging 

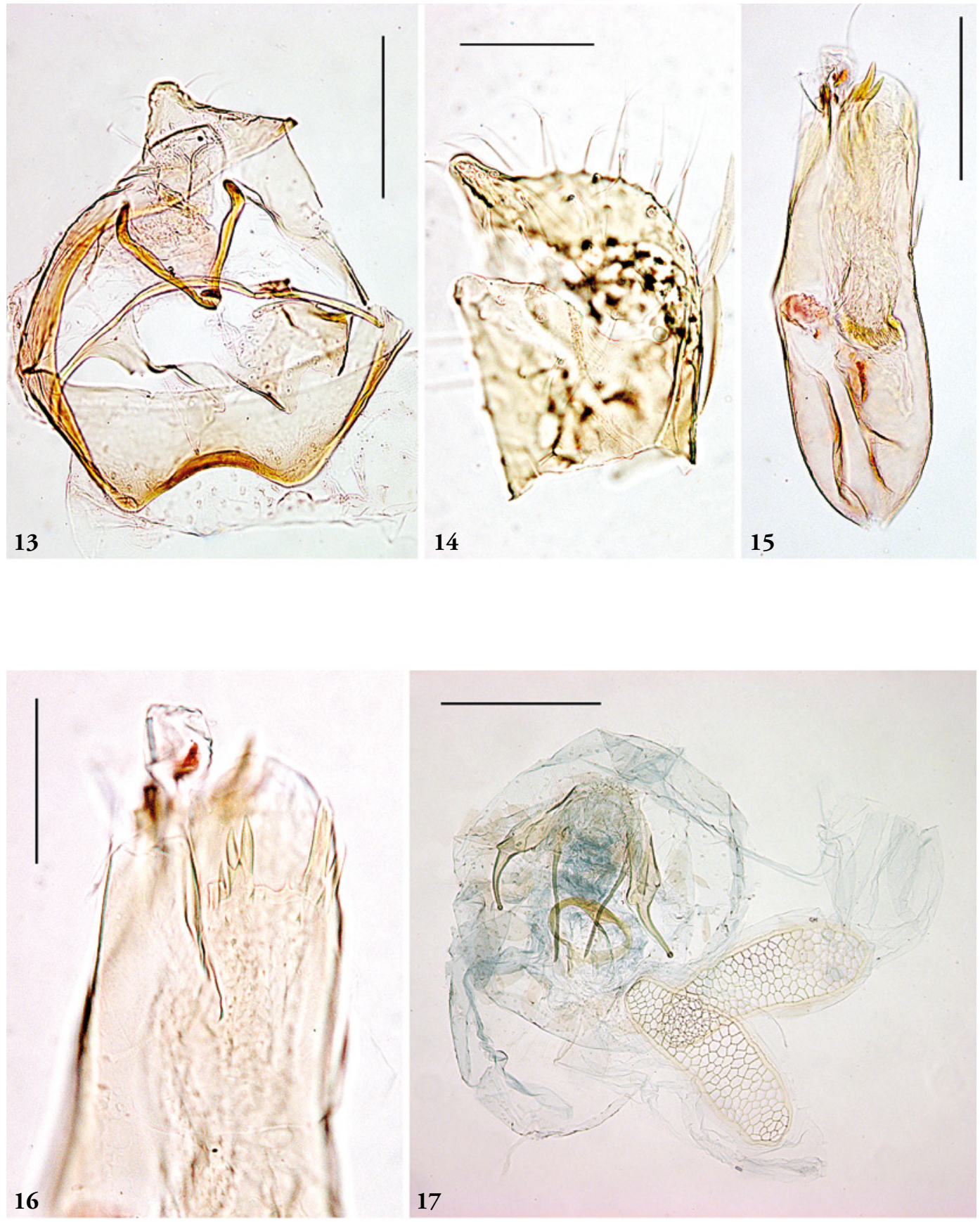

Figs 13-17. Ectoedemia marmaropa, genitalia. - 13-16, Male holotype, slide PJN131, resp. capsule, valva, aedeagus ventrally and detail dorsally; 17, female paratype, slide PJN132. Scales $100 \mu \mathrm{m}(13,15), 50 \mu \mathrm{m}(14,16)$ and $200 \mu \mathrm{m}(17)$. 
into large mine; exit-slit on upperside. Cocoon dark fuscous, spun on leaf litter.

Voltinism. Univoltine. Larvae were collected from 16-19 August; adults emerged indoors in April (after hibernation in an outhouse until March), in Norway collected from 5-16 June.

Habitat. Both localities share a limestone soil and a relatively dry and warm summer climate with around $500 \mathrm{~mm}$ annual precipitation and a snow cover in the cold winter. The French locality (Fig. 24) is a Pinus sylvestris forest along a mountain stream in a high alpine valley (ca. $1375 \mathrm{~m}$ ) with shrubs such as Alnus incana, Sorbus aucuparia, Lonicera xylosteum, Salix species and Rosa species.

The Norwegian locality (Fig. 25) is a southwestern exposed steep mountain slope, about 600-900 m, above a lake, with an open grassland vegetation, very rich in herbs, open scree and rocks and some low shrubs: Juniperus vulgaris, and Rosa majalis close to a deciduous forest with Corylus avellana, Populus tremula, Cotoneaster integerrima, Alnus incana, Salix species, Ribes, Prunus padus, Sorbus aucuparia and Betula. The place is one of the first in the area to be free of snow in spring (March).

\section{Distribution (Fig. 26)}

France: Briançon area and Norway: Vang.

\section{DNA barcode}

The barcodes are discussed by van Nieukerken et al. (2012). Genbank accession numbers (with RMNH registry numbers) for the COI sequences are JN201601 (RMNH.INS.23911), JN201603 (RMNH.INS.23741), JN201608 (RMNH. INS.12588), JN201609 (RMNH.INS.12587).

\section{Etymology}

Named after the hostplant genus. The epithet rosae is a noun in genitive case.

\section{Keys}

In the key to adult male Ectoedemia (van Nieukerken 1985), E. rosae runs to couplet 37, which can be changed as follows:

37. Very small species, forewing length 1.7$2.1 \mathrm{~mm}$. Male without hair-pencil. Aedeagus with spinose dorsal process and ventral carinae. Female genitalia with vaginal sclerite. Feeds on Filipendula vulgaris ... 42. hexapetalae

- Small species, forewing length 2.0-2.3 mm. Male with white hair-pencil, and forewing underside with basal patch of white androconial scales. Aedeagus with spinose dorsal process and ventral carinae. Female genitalia with vaginal sclerite. Feeds on Rosa .. 42a. rosae

$=$ Larger, forewing length $2.2-2.5 \mathrm{~mm}$. Male with yellowish white hair-pencil. Aedeagus without carinate processes. Female genitalia without vaginal sclerite. Feeds on Spiraea . .

40. spiraeae

In the key to the male genitalia it runs to $18, E$. hexapetalae; differences lay in the larger size of all parts in $E$. rosae, the larger number of spines on the ventral carinae and the divided gnathos in rosae.

In the key to the female genitalia, couplet 6 can be changed as follows to incorporate $E$. rosae:

6. Corpus bursae without pectinations, completely smooth outside signa. A group of densely packed pectinations present in vestibulum

- Corpus bursae without pectinations, completely smooth outside signa. Densely packed pectinations in vestibulum absent ....42a rosae

$=$ Corpus bursae mostly covered with small pectinations or spines. Densely packed pectinations in vestibulum may be either present or absent

\section{Other Rosa feeding species}

In Europe the only other Rosa feeder in the genus is E. angulifasciella (Stainton, 1849), which can easily be distinguished by the pale head tuft and metallic silver fascia. The mines of this species have a more elongate blotch that is less separated from the gallery, and the larva has a dark head and conspicuous ventral plates in the earlier instars (illustrations see e.g.: Bengtsson et al. 2008, Edmunds 2011, Ellis 2010, van Nieukerken \& Johansson 1990). Other Rosa feeders belong to Stigmella, and are all characterised by the gallery leafmine and larva feeding with dorsum upwards.

Outside Europe the following Rosa feeding Ectoedemia's have been described: Ectoedemia marmaropa (Braun 1925) from North America (Rocky Mountains), E. rosiphila Puplesis, 1992 (in Puplesis et al. 1992) from Kazakhstan (Tian Shan) and E. picturata Puplesis 1985 from eastern Russia and China (van Nieukerken \& Liu 2000, Puplesis 1994). Further undescribed species from Rosa have been seen by the senior author from Japan and China: Yunnan. From all these species, illustrated mines of E. marmaropa and $E$. rosiphila are strikingly similar to those of $E$. rosae. Since these three species possibly form a closely related group of montane species, we briefly discuss these two species here. 

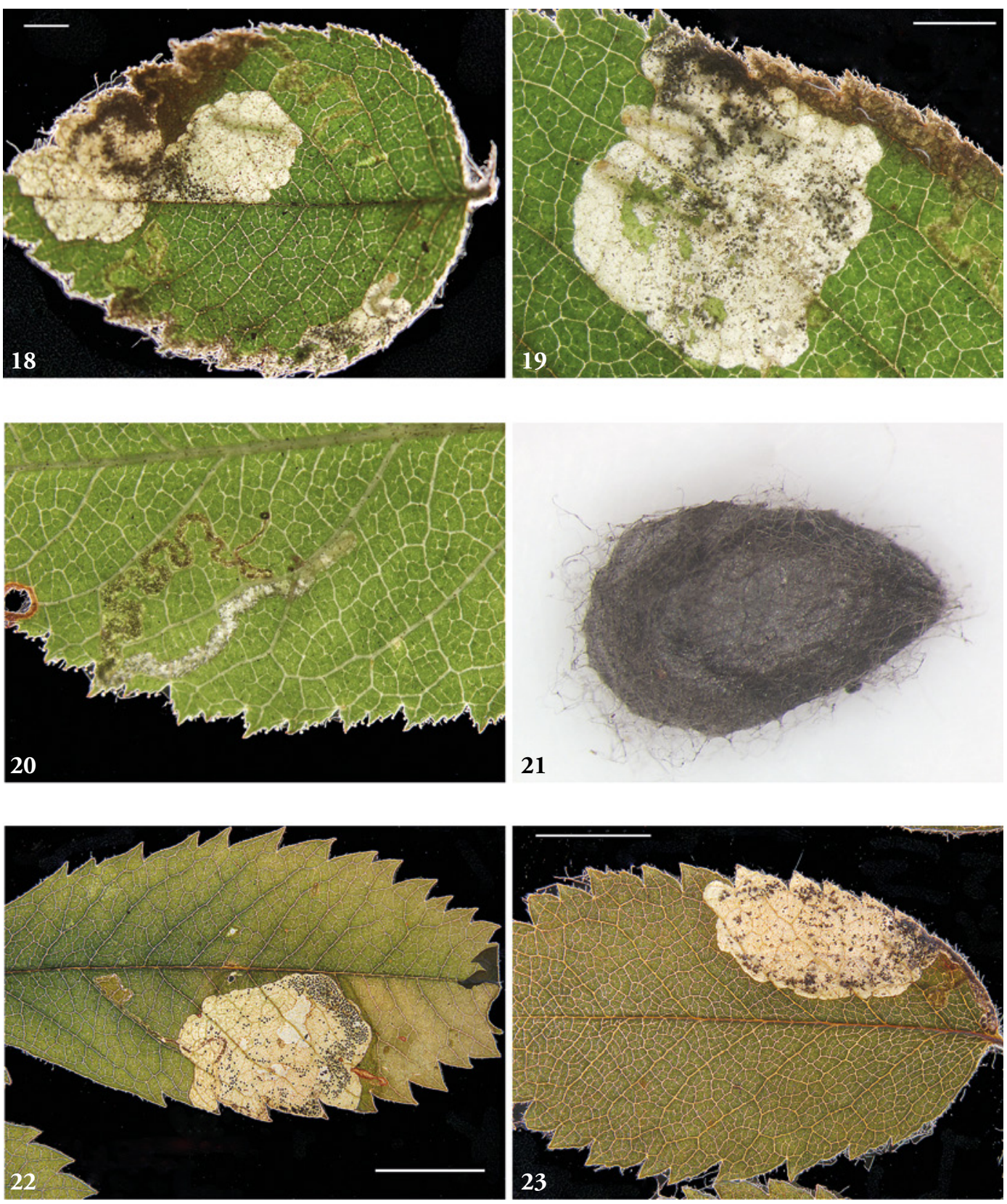

Figs 18-23. Leafmines and life history of Ectoedemia. - 18-20, E. rosae on Rosa tomentosa, type locality, mines with living larvae, 20 shows a young mine from the underside; 21, E. rosae cocoon; 22, 23, E. marmaropa, vacated mines from EvN88241, British Columbia, Vaseux Lake Park and EvN88261, Alberta, Jasper NP. Scales 2 mm (18-20), $1 \mathrm{~mm}(21), 5 \mathrm{~mm}(22,23)$. 


\section{Ectoedemia marmaropa (Braun)}

Figs 13-17, 22, 23

Nepticula marmaropa Braun 1925: 225. Holotype ô: USA: Utah, Cache Co., i. 23.iv.1925, A.F. Braun, Genitalia slide PJN131 (ANSP) [examined].

Ectoedemia marmaropa; Wilkinson \& Newton 1981: 49 [recombination, redescription]

Diagnosis. Externally this species is rather different with the forewing dark brown with bronze and golden reflections, becoming irrorate distally; there is a basal patch dusted with gray and a convex, shining silver, postmedial fascia. The hairpencil is absent (Don Davis, pers. com.). The male genitalia (Figs 13-16) are similar to those of E. rosae and $E$. hexapetalae and have the dorsal medial process (Fig. 16) with less spines than rosae, and the ventral carinae (Fig. 14) each bifid. The female genitalia (Fig. 17) are very similar to those of E. rosae.

Biology. Described from Rosa woodsii Lindl., later records are from Rosa californica Cham. \& Schldl. and unidentified Rosa species. Egg on leaf underside. Leafmine (Figs 22-23) starts as narrow gallery with central line of broken black frass, sometimes more or less contorted, later suddenly enlarging in elongate blotch with dispersed frass. Larva pale whitish green. Apparently univoltine, larvae found in mid July, and in California in September, adults were reared in April, cited females below (if correctly identified) were taken in June and early July.

Distribution. USA and Canada: Rocky Mountains and more western mountain ranges, described from Utah, later recorded from Wyoming (Grand Teton NP) (Wilkinson \& Newton 1981). The record of leafmines from Ohio [on Rosa woodsii!], cited in the same paper is very unlikely and probably a mislabelling, especially since Rosa woodsii is a western species that does not occur in Ohio.

Here we record E. marmaropa somewhat tentatively new for Canada (Alberta and British Columbia) and for California on the basis of the following records:

Canada, Alberta: 1 \% , $150 \mathrm{~km} \mathrm{NW}$ Banff, bed of R. Saskatchewan, $1200 \mathrm{~m}$, sandy meadow, 1.vii.1994, M. Ahola \& L. Kaila (MZH); 2 vacated leafmines: Jasper: Wapiti campground, $1050 \mathrm{~m}$, 29.vii.1988, Rosa spec., EvN 88261, E.J. van Nieukerken (RMNH). British Columbia: 1 vacated mine, Paul Lake park, 17 km NE Kamloops, 800-850 m, 2.viii.1988, Rosa spec., EvN 88277 E.J. van Nieukerken (RMNH); 1 larva [rearing failed], 2 vacated mines, Vaseux Lake Park, 6 km SE Okanogan Falls, 330 m, 17.vii.1988, Rosa spec., EvN 88241 E.J. van Nieukerken (RMNH). USA, California: leafmines, Alpine Co., Jct Hwy 4 \& 89, 12.ix.1981, Rosa woodsii, JAP no. 81J30 D.L. Wagner (Wagner coll.); 1 o Plumas Co., 1 mi S meadow Valley, 1-3.vi.1984, D.L. Wagner (Wagner coll.); leafmines [rearing failed], same locality, 12.ix.1983, JAP No 83J49, Rosa californica, D.L. Wagner (Wagner coll.).

\section{Ectoedemia rosiphila Puplesis}

Ectoedemia rosiphila Puplesis in: Puplesis et al. 1992: 55. Holotype $\hat{0}$ : Kazakhstan, $90 \mathrm{~km}$ E Chimkent, Aksu Dzhabagly Reserve, 20.viii.1987, larva in Rosa sp., R. Puplesis (VPU) [re-examined by J.R. Stonis, A. Diškus and A. Navickaite, in litt. September 2011]

Diagnosis. This species is only known from the rather damaged holotype. From the original and later descriptions (Puplesis et al. 1992, Puplesis 1994) and the recent re-examination it appears that externally the species differs by the absence of a hairpencil and different wing pattern: basal area of forewing very pale. Head colour unknown (head missing). Male genitalia gnathos with large central element; apical process of valva more prominent than in $E$. rosae, inner margin of valva straight, valva narrow; vinculum short compared to E. rosae. Aedeagus dorsally with a few (2 larger and 2-3 smaller) spines on medial carina, all spines less sclerotized, less visible than in E. rosae. These spines are not shown in Puplesis (1994: Fig. 653) similar to other numerous tiny spines (cornuti) that were discovered on the vesica of rosiphila during the recent re-examination.

Biology. On Rosa sp. The mine looks very similar to those of E. rosae and E. marmaropa.

Distribution. Probably common in the mountainous areas of Central Asia. Similar mines were observed in several mountains of Kazakhstan and Tajikistan (Puplesis et al. 1992).

\section{Discussion}

Several characters in the genitalia point to a close relationship between $E$. rosae, E. marmaropa, E. rosiphila and E. hexapetalae. All live on Rosaceae, and apart from E. hexapetalae, on Rosa in high mountains: Rocky mountains, Tian Shan and Tadjikistan, Alps and Scandinavian mountains. E. rosae, E. rosiphila and E. marmaropa seem to be very closely related considering the similarity in genitalia. These species may represent relicts from a species that had a wide distribution in the Holarctic in colder periods in or before the Pleistocene.

Despite the continuously increasing collecting effort of small moths and leafmines all over Europe, it is 

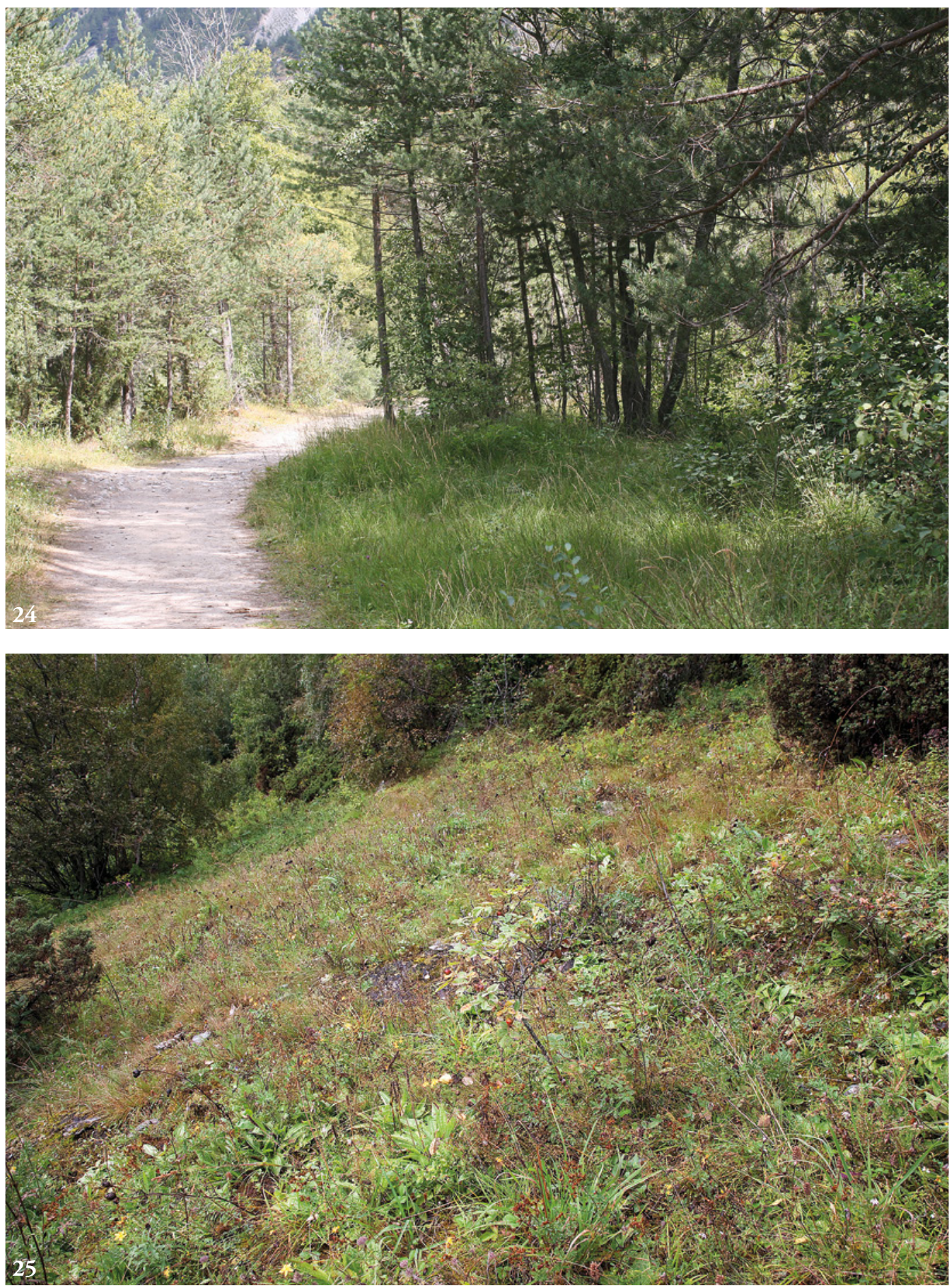

Figs 24-25. Habitat of Ectoedemia rosae. - 24 (top), France, type locality, Vallée de la Clarée, Le Bois de Boulogne, path close to the river: the rose bushes with mines were all close to the path, photo Erik van Nieukerken; 25 (bottom), Norway, Vang, Døtten, steep slope with herbs and small shrubs. The specimens were beaten from the rose bushes as shown in the middle of the photograph, photo Thor Østbye, taken August 2011. 


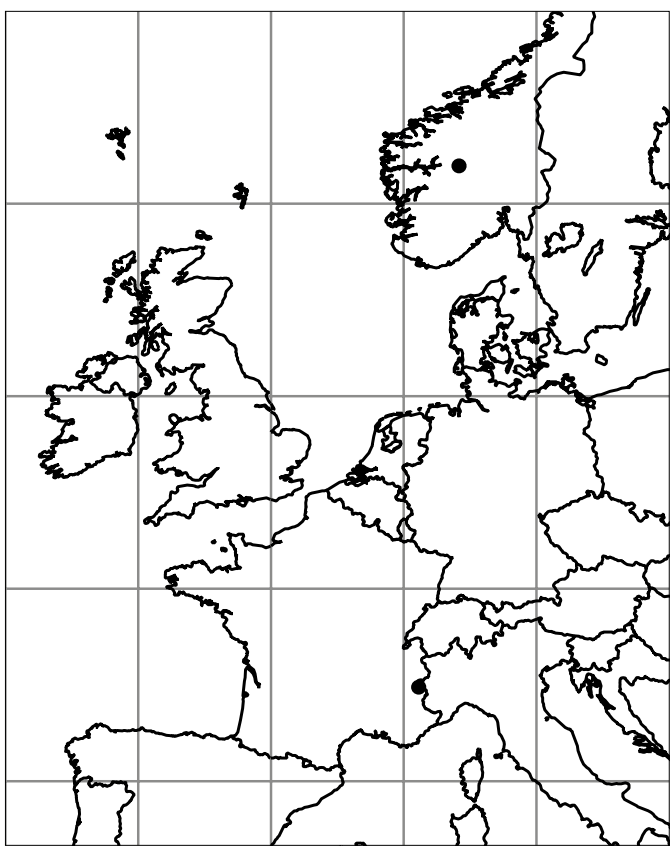

Figs 26. Distribution of Ectoedemia rosae.

apparently still possible to discover a completely unknown species in the French Alps or the middle of Norway, even with rather conspicuous leafmines. It could be that the species was simply overlooked or confused with $E$. angulifasciella. However, searching the literature on alpine Nepticulidae (e.g. Klimesch 1961) has not given any indication that the species had been found before. In the collection of Alpine Lepidoptera in Innsbruck amongst Ectoedemia there was no similar specimen (P. Huemer personal communication). Still, we think that it is likely that $E$. rosae is yet to be discovered in some of the xeromontane Alpine valleys, such as Wallis or de Valle $\mathrm{d}$ 'Aosta, and in more places near Briançon, where leafmine collecting has been scarce, but the disjunct distribution seems to be true and not a collecting artefact. The similarity of the collection sites: rather dry limestone areas on relatively high altitude is also remarkable. Both areas have a very diverse Lepidoptera fauna with rare species (E. Drouet pers. comm., for Briançon; personal data KB for Vang).

This reminds of a similar case in Gelechiidae: Scrobipalpa reiprichi Povolný, 1984, a species found in another warm and dry locality in central Norway: Vinstra and elsewhere only from one locality in Slovakia and Hungary, possibly in Greece (Karsholt et al. 1986, Huemer \& Karsholt 2010). However, this species has now also been recorded from Far East Russia and China (Huemer \& Karsholt 2010).

Both disjunct distributions could be relicts of former wider distributions during the Pleistocene, and it resembles many boreo-alpine distributions, although they usually have larger distributions both in the Central European mountains and Scandinavia (see e.g. Mani 1968). The observed barcode difference of $1.5 \%$ between Norwegian and French populations (as reported by van Nieukerken et al. 2012) further are an indication for isolated populations.

Because of the rarity of Ectoedemia rosae, and its specific habitat, the species might be under threat, particularly since climate change often affects northern and montane species negatively (eg Thuiller et al. 2005, Parmesan et al. 1999). It would therefore be important to evaluate whether the localities need further protection. In France touristic development might form a threat, despite the fact that the area has many protected parts. An inventory of the species by searching for mines in August might be the best way both in the Alps and Norway to understand the extent of its distribution and the need for its protection.

\section{Acknowledgements}

We are grateful to colleagues Kees van den Berg and Camiel Doorenweerd (NCB Naturalis, Leiden) for assistance with rearing and preparation of specimens. Camiel Doorenweerd did also the molecular work cited above and provided some suggestions for improving the text. Don Davis (USNM, Washington) is acknowledged for the loan of the holotype slide of E. marmaropa, Lauri Kaila (FMNH, Helsinki) for the loan of unidentified material from North America and David Wagner (University of Connecticut, Storrs, USA) for the loan of Californian material. J.R. Stonis, A. Diškus and A. Navickaitè (Vilnius, Lithuania) kindly re-examined the holotype of E. rosiphila and reviewed the paper. Leif Aarvik (Oslo, Norway) is acknowledged for bringing the authors in contact and for advise, and Bengt $\AA$. Bengtsson (Färjestaden, Sweden) for his information on the French locality which lead to the discovery of this species, Peter Huemer (Museum Ferdinandeum, Innsbruck) for information on Ectoedemia in their collection and critical comments on the manuscript, and Eric Drouet (St.-Herblain, France) for information on Lepidoptera from Briançon. Thor Østbye (Vang, Norway) was so kind to take a photograph of the Norwegian locality and allow us to publish it here. 


\section{References}

Bengtsson, B.Å., R. Johansson \& G. Palmqvist, 2008. Nationalnyckeln till Sveriges flora och fauna ( = Encyclopedia of the Swedish Flora and Fauna), DE 1-13. Fjärilar: Käkmalar - säckspinnare. Lepidoptera: Micropterigidae - Psychidae. - ArtDatabanken, SLU, Uppsala. 646 pp.

Braun, A.F., 1925. Microlepidoptera of Northern Utah. - Transactions of the American Entomological Society 51: 183-226.

Edmunds, R., 2011. British leafminers. - http://www. leafmines.co.uk/index.htm

Ellis, W.N., 2010. Bladmineerders van Europa / Leafminers of Europe. - http://www.bladmineerders.nl/index.htm

Evenhuis, N.L., 2007. The insect and spider collections of the world website. - Bishop Museum. http://hbs. bishopmuseum.org/codens/codens-r-us.html

Huemer, P. \& O. Karsholt, 2010. Microlepidoptera of Europe, 6. Gelechiidae II (Gelechiinae: Gnorimoschemini). - Apollo Books, Svendborg. 586 pp.

Karsholt, O., K. Larsen \& L. Aarvik, 1986. A remarkable disjunction: Scrobipalpa reiprichi Povolny, 1984 discovered in Norway, with remarks on the characteristics of the species (Lepidoptera: Gelechiidae). - Nota Lepidopterologica 9: 191-199.

Klimesch, J., 1961. Ordnung Lepidoptera. 1. Teil. Pyralidina, Tortricina, Tineina, Eriocraniina und Micropterygina. - In: H. Franz (Ed.), Die Nordost-Alpen im Spiegel ihrer Landtierwelt. 2: 481-789. Universitätsverlag Wagner, Innsbruck.

Mani, M.S., 1968. Ecology and biogeography of high altitude insects. - Junk, Den Haag. 527 pp.

Nieukerken, E.J. van, 1985. A taxonomic revision of the western Palaearctic species of the subgenera Zimmermannia Hering and Ectoedemia Busck s. str. (Lepidoptera, Nepticulidae), with notes on their phylogeny. - Tijdschrift voor Entomologie 128 (1): 1-164. http://biodiversitylibrary.org/page/30334755

Nieukerken, E.J. van \& R. Johansson, 1990. Tribus Trifurculini. - In: R. Johansson, E.S. Nielsen, E.J. van Nieukerken \& B. Gustafsson (Eds.), The Nepticulidae and Opostegidae (Lepidoptera) of NW Europe. - Fauna Entomologica Scandinavica 23: 239-321.

Nieukerken, E.J. van \& Y. Liu, 2000. Nepticulidae (Lepidoptera) in China, 1. Introduction and Stigmella Schrank feeding on Fagaceae. - Tijdschrift voor Entomologie 143 (2): 145-181. http://www.nev.nl/tve/cat/ info.php?artikelid=2321

Nieukerken, E.J. van, A. Laštůvka \& Z. Laštůvka, 2006. Annotated catalogue of the Nepticulidae and Opostegidae (Lepidoptera: Nepticuloidea) of France and Corsica. - Zootaxa 1216: 1-114. http://www.mapress. com/zootaxa/2006/zt01216p114.pdf
Nieukerken, E.J. van, A. Laštůvka \& Z. Laštůvka, 2010. Western Palaearctic Ectoedemia (Zimmermannia) Hering and Ectoedemia Busck s. str. (Lepidoptera: Nepticulidae): five new species and new data on distribution, hostplants and recognition. - ZooKeys 32: 1-82. Doi: $10.3897 /$ zookeys.32.282

Nieukerken, E.J. van, C. Doorenweerd, F.R. Stokvis \& D.S.J. Groenenberg, 2012. DNA barcoding of the leaf-mining moth subgenus Ectoedemia s. str. (Lepidoptera: Nepticulidae) by COI and EF1- $\alpha$ : two are better than one in recognising cryptic species. - Contributions to Zoology 81 (1): accepted.

Parmesan, C., N. Ryrholm, C. Stefanescu, J.K. Hill, C.D. Thomas, H. Descimon, B. Huntley, L. Kaila, J. Kullberg, T. Tammaru, W.J. Tennent, J.A. Thomas \& M. Warren, 1999. Poleward shifts in geographical ranges of butterfly species associated with regional warming. - Nature (London) 399 (6736): 579-583. Doi: $10.1038 / 21181$

Puplesis, R., S. Seksjaeva, R. Noreika \& J. Puplesiene, 1992. Some leaf-mining Lepidoptera from the Aksu Dzhabagly Reserve (western Tian Shan) with the descriptions of four new species (Lepidoptera: Nepticulidae, Bucculatricidae). - Nota Lepidopterologica 15 (1): 47-64.

Puplesis, R., 1994. The Nepticulidae of eastern Europe and Asia. Western, central and eastern parts. - Backhuys Publishers, Leiden. 290 pp.

Puplesis, R.K., 1985. Novye vidy moleï-malyutok (Lepidoptera, Nepticulidae) s yuga dal'nego vostoka i Tadzhikistana (New species of the nepticulid moths from Southern far east and Tadzhikistan). - Trudy Zoologicheskogo Instituta. Akademiya Nauk SSSR 134: 59-72.

Thuiller, W., S. Lavorel, M.B. Araújo, M.T. Sykes \& I.C. Prentice, 2005. Climate change threats to plant diversity in Europe. - Proceedings of the National Academy of Sciences of the United States of America 102 (23): 8245-8250. 10.1073/pnas.0409902102

Wilkinson, C. \& P.J. Newton, 1981. The micro-lepidopteran genus Ectoedemia Busck (Nepticulidae) in North America. - Tijdschrift voor Entomologie 124 (2): 27-92. http://biodiversitylibrary.org/page/28244920

Received: 3 September 2011

Accepted: 7 October 2011 


\section{Book reviews}

Gaden S. Robinson, 2009. Biology, distribution and diversity of tineid moths. Southdene $S \mathrm{dn}$ Bhd, in association with the Natural History Museum, London. ISBN 9789834005399 , hardcover, 143pp. Price $£ 40.00$.

This remarkable book deals with the world fauna of the tineids, to which the well known clothes moths belong. The family is peculiar amongst the plant eating Lepidoptera as only very few of the species eat living plant material, whereas most species live from dead or decaying organic material, including animal products with keratin (feathers, hairs) and fungi.

The book is not a revision, key or phylogenetic treatment. The author refers to his earlier works for those interested in these aspects. Also a checklist of the about 2400 species is not in the book, because it is available online (http://www.nhm. ac.uk/research-curation/research/projects/tineidae/).

After a general introduction there is a humoristic chapter why the author choose to study this family, written in a style where the author addresses the moths, answering the question: "Why Tineidae why pick on us?".

In a next section, there is a brief review of the classification, enumerating the subfamilies and the genera, providing brief characteristics and numbers of species.

The gist of the book is formed by the second chapter: Distribution and diversity. The author treats in much detail the faunas of all geographic regions, particularly with detailed descriptions of island fauna. His interest for islands is no surprise, after the author's $\mathrm{PhD}$ thesis on Fiji moths. It is a very instructive chapter to read, even with all the enumerations of names. Many details are given for species that are mentioned, including biology, distribution, introduction of species, with many references provided. I do not know of similar global reviews of Lepidoptera groups, and I think it is a very good way to describe diversity of a family. It clearly shows that tineids are more than just clothes moths.

The book ends with a set of colour plates, illustrating more than 500 species. These plates are the most disappointing part of the book, they were not well prepared graphically and the printing does not do justice to these often unexpectedly colourful moths. The contrast is poor between the grey background

\section{Biology, distribution and diversity of tineid moths}

\author{
Gaden S. Robinson
}

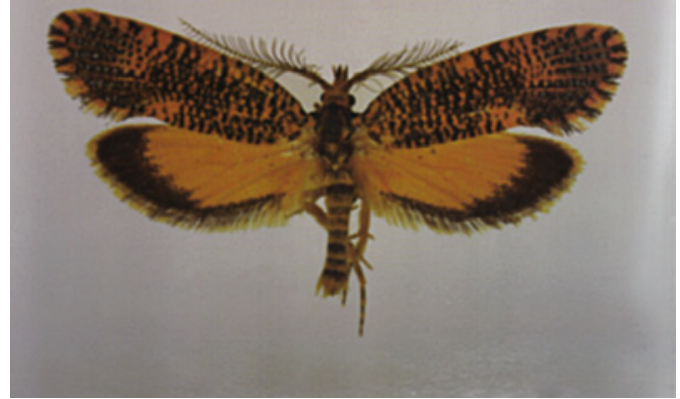

and drab looking photographs, the moths do not look sharp and are also all brought on about the same size, whether they measure actually $17 \mathrm{~mm}$ or just $2 \mathrm{~mm}$. Still it is the first collection of so many tineid moths in colour and definitely will serve in recognising an identifying many of these moths., many of which are illustrated in colour for the first time ever.

As could be expected with this author, the book is well written and a pleasure to read.

Sadly the author did not live to see the book in print, he died on 7 September 2009 at the age of 60, during the preparation phase. Just before going to print a short obituary could be included at the beginning of the book. In this way the book could become the real testimony of Gaden Robinson, although the author was well aware that this was his last publication, as can be read between the lines in several places.

This book is warmly recommended to all who have an interest in Lepidoptera diversity, but also for biologists with a more general interest in biodiversity, particularly on islands.

Erik J. van Nieukerken 